\title{
Expectations and Standards of International Students from Teachers and Peers
}

\author{
Dr. Anil Kumar Palla \\ Dr. Jerry Jackson \\ Kiran Kumar Palla
}

\begin{abstract}
This paper will analyze much of the literature that already exists surrounding the ways that international students are exposed to expectations and standards on all sides from both teachers and peers. The differences in the ways that peers and teachers both put forth these expectations and standards will be analyzed in-depth here as well. In the process, some of the most prominent of literature on these topics will be examined, summarized, and reviewed. This will allow for a more retrospective and contemporary understanding of these concepts to be gleaned here. In analyzing each of these important elements, it will be made clear that there should be more unified expectations and standards unilaterally for the education system of the United States, but especially for these international students here. The gaps that exist in this regard will be examined and analyzed, and then discussed, within the literature here.
\end{abstract}

Keywords: expectations, international, students, teachers, peers

When it comes to the expectations and standards that exist within the purview of international students, both at the undergraduate and graduate levels, from their teachers and peers, there are a large number of individual, intrinsic factors here that make this much greater than the sum of their parts. For one thing, teachers have a unique way of analyzing and expecting things from all students, not just these international students, that helps to provide a unique perspective here that can be applied in a large number of ways. On the other hand, the peers of these international students similarly have a unique way of looking and thinking about them that causes them to create their own unique set of both expectations and standards. Looking at it in this regard, the dichotomy that can be observed here implies a great deal about how these international students, both at the graduate and undergraduate level, are perceived. Therefore, in order to better understand some of these differences, it is necessary to examine some of the most prominent literature on the subject.

For starters, international students are perceived differently within English-speaking universities, especially by the teachers there, and this is a concept mentioned by some of the literature. According to one source, for instance, there is a fundamental lack of knowledge and understanding of both graduate and undergraduate international students within these universities on the part of the teachers (Andrade, 2006). To ameliorate this, the source posits that there must be a greater amount of focus placed on educating teachers, in particular, as to the specifics of these international students. Furthermore, another source here actually states that attitudes of teachers toward international students in general at the graduate level, that there was a large amount of awareness as to the problems that were faced by these international students in many different fields, including that of architecture, mechanical engineering, materials science, and many others (Trice, 2003). This means that when it comes to graduate students, there seems to be more of a degree of awareness on the part of the teachers, whereas for undergraduate students, this awareness is far less prominent. One of the key catalysts of greater amounts of expectations and overall standards and awareness on the part of these teachers toward graduate international students, as opposed to undergraduate, is because of what these graduate students can bring to the table.

Indeed, another source states that the diversity of international students actually brings about a large number of benefits for universities the world over. Perhaps most importantly, as this source points out, these international students function as a prominent source of income, especially for Asian and African international students studying in Western universities (Biggs, 2011). Essentially, this increased income potential means that there is more and more of a need for higher expectations, particularly for these graduate international students, because it will allow for their potential, and the profit intrinsic to that, to be maximized as much as possible here. 
Another source elucidates on some of the psychological fundamentals of this by stating that students formulate approximately fifty percent of the variance of achievement, as it is called here, and this means that higher levels of expectations on the level of both peers and, especially, teachers, will facilitate the maximizing of this variance of achievement for these graduate and undergraduate international students (Hattie, 2003). Furthermore, the source also points to there being a high correlation between ability and achievement here, helping to explain why there are so many high standards by teachers here (Hattie, 2003).

It seems that there is a more pragmatic reason for these teachers having higher expectations and standards of international students as a whole, and this element is one that is explained by some of the literature here. Indeed, according to another source, teachers that have more of a hands-on approach to expectations and standards are more likely to have positive results from their students as a whole, and this leads to these international students having a greatly increased chance of success here (Rockoff, 2003). This is a concept that is alluded, to some extent, by another article, which states that, moving forward, higher education will need to take a more globalized perspective when it comes to the establishment of both expectations and standards because of the ever-increasing number of international students that will come about here (Ramsden, 2008). Another source makes mention of some of these concepts, at least in the more globalized sense, by stating that there exists a need for more stark understanding and standards when it comes to science as a whole for international students of both the undergraduate and graduate levels (McComas \& Olson, 1998). This, the source states, would allow for the establishment of more diverse and concrete standards here that would greatly improve the educational system as a whole, including for these international students (McComas \& Olson, 1998).

The concept of peer assessment is one that is generally discarded when it comes to the purview of both expectations and standards surrounding these international students. However, as another source points out, student peer assessment, for these international students as well, is crucial because it allows for some of the fundamental learning processes to be smoothed out and facilitated that much more in order to ensure that these international students, at both the graduate and undergraduate levels, are able to find success that much more easily (Falchikov\& Goldfinch, 2000). Furthermore, another source states that higher standards, on the level of both the teachers themselves and the peers of these international students, are positively correlated with more long-term and concrete results, even when these standards might, at first, appear to be far too strict or rigid as a whole (Darling-Hammond \& Ball, 1998). Another important dimension of this is the way that peers lead to the increasing of standards for these international students on a more unofficial, for lack of a better term, level. This concept is one that is mentioned by another source, which finds that various empirical analyses that have been conducted have demonstrated a profound number of peer effects when it comes to the formulation of both expectations and standards here, to the point where the exact effects are as of yet unknown (Hanushek, Kain, Markman \& Rivkin, 2003).

Despite the numerous benefits that can be observed when it comes to the formulation of these expectations for international students, especially on the part of the teachers themselves, there are still a large number of problems associated with this. According to another source, for instance, there is a gap between expectations in terms of international students and teachers themselves, and this gap leads to numerous dichotomies in standards and overall perceptions of these international students at virtually every level, hampering their long-term success in the process (Kingston \& Forland, 2008). One of the proposed solutions here is to increase the overall level of interaction between peers and these international students, in terms of the ways that they put forth expectations and standards. For example, another article posits that the use of things like social media could actually be leveraged in order to better communicate the ways that peers are considering these international students, including the standards and expectations that they are setting for them (Dippold, 2009). This will allow for an increase in both awareness and communication that will improve these international students at both the undergraduate and graduate levels.

International student achievement is one particular purview that does not seem to be as well-understood, within a more official context, as most other elements here, and as a result, there has been a large amount of research dedicated to better understanding this. According to one source, for instance, higher levels of teacher engagement will also almost certainly lead to higher levels of both expectations and standards here, and it is easy to see just how and why this would apply to these international students as well here (Newmann, 1992). At the same time, though, there are many who believe that the formulation of these expectations and standards still leaves much to be desired. 
For instance, another source points out that there is still a stark need for both professional development as well as reform within science education, which is one of the core areas of education and learning that tends to be focused on by international students, both at the graduate and undergraduate levels (Van Driel, Beijaard \& Verloop, 2001). Furthermore, another source actually states that the use of accountability imperatives, as they are referred to here, are becoming more and more prominent because they allow for standards-driven accountability to be facilitated that much more easily (McTighe \& Brown, 2005). Quite simply, this means that establishing standards that focus on student achievement will go a long way toward improvement of the overall way that international students have their standards formulated for them.

One of the core gaps that exists when it comes to formulating these expectations for international students, at least, is that of the gap in teaching effectiveness. To help ameliorate this, another source states that there exist numerous strategies that can be leveraged to measure and subsequently improve teaching effectiveness as a whole, such as that of utilizing quantitative peer ratings, as well as self-evaluation (Berk, 2005). Each of these individual elements can easily be extrapolated to apply to international students at the graduate and undergraduate levels quite easily as well. Furthermore, another source actually points out that there is a need to improve student attainment at the international level, and that this can be facilitated by being transparent about expectations, especially as these expectations relate with reducing some of the core weaknesses of each of these international students (Dochy, Segers \& Sluijsmans, 1999). As this same source points out, this will necessitate a more personal approach to this in order to better elucidate how this can occur, which will, by extension, require something of a restructuring of the conventional methods of teaching and learning as a whole (Dochy, Segers\&Sluijsmans, 1999).

Lastly, the use of peer feedback is instrumental to the overall level of success that can be observed here. This element is one that is explained by another source, which finds that peer feedback allows for a more transparent provision of both expectations and standards to students in general (Ertmer, Richardson, Belland, Camin, Connolly, Coulthard \& Mong, 2007). This alludes to the ways that teachers and peers can both extrapolate some of the fundamentals of these concepts in order to improve the ways that expectations and standards are created here. The United States is historically a country that has been welcoming for international students, but at the same time, there are nonetheless a large number of elements that can be improved a great deal here.

Ultimately, it seems that the expectations and standards that are being crafted for international students, at both the graduate and undergraduate levels, require a great deal more restructuring, as well as additional research, in order to ensure that they are able to remain as effective as possible. This is because international students in the United States find themselves at the center of a virulent and oftentimes confusing series of philosophies, laws, expectations and standards. Creating a more unified system of standards and expectations would go a long way toward improving these outcomes in the long term here as well. Despite the fundamental lack of existing standards and expectations, relative to other countries, there can be little doubt that there is still a great deal of potential for improvement.

\section{References}

Andrade, M. S. (2006). International students in English-speaking universities: Adjustment factors. Journal of Research in International education, 5(2), 131-154.

Berk, R. A. (2005). Survey of 12 strategies to measure teaching effectiveness. International journal of teaching and learning in higher education, 17(1), 48-62.

Biggs, J. B. (2011). Teaching for quality learning at university: What the student does. McGraw-Hill Education (UK). p.4

Darling-Hammond, L., \& Ball, D. L. (1998). Teaching for high standards: What policymakers need to know and be able to do.

Dippold, D. (2009). Peer feedback through blogs: Student and teacher perceptions in an advanced German class. ReCALL, 21(1), 18-36.

Dochy, F. J. R. C., Segers, M., \&Sluijsmans, D. (1999). The use of self-, peer and co-assessment in higher education: A review. Studies in Higher education, 24(3), 331-350. 
Ertmer, P. A., Richardson, J. C., Belland, B., Camin, D., Connolly, P., Coulthard, G., ... \&Mong, C. (2007). Using peer feedback to enhance the quality of student online postings: An exploratory study. Journal of Computer-Mediated Communication, 12(2), 412-433.

Falchikov, N., \& Goldfinch, J. (2000). Student peer assessment in higher education: A meta-analysis comparing peer and teacher marks. Review of educational research, 70(3), 287-322.

Hanushek, E. A., Kain, J. F., Markman, J. M., \& Rivkin, S. G. (2003). Does peer ability affect student achievement? Journal of applied econometrics, 18(5), 527-544.

Hattie, J. (2003). Teachers Make a Difference, What is the research evidence?

Kingston, E., \&Forland, H. (2008). Bridging the gap in expectations between international students and academic staff. Journal of Studies in International Education, 12(2), 204-221.

McComas, W. F., \& Olson, J. K. (1998). The nature of science in international science education standards documents. In The nature of science in science education (pp. 41-52). Springer, Dordrecht.

McTighe, J., \& Brown, J. L. (2005). Differentiated instruction and educational standards: Is détente possible. Theory into Practice, 44(3), 234-244.

Newmann, F. M. (1992). Student engagement and achievement in American secondary schools. Teachers College Press, 1234 Amsterdam Avenue, New York, NY 10027 (paperback: ISBN-0-8077-3182-X, \$17.95; hardcover: ISBN-0-8077-3183-8, \$38)..

Ramsden, P. (2008). The future of higher education teaching and the student experience. The Higher Education Academy. Retrieved March 30, 2010.

Rockoff, J. E. (2004). The impact of individual teachers on student achievement: Evidence from panel data. American Economic Review, 94(2), 247-252.

Trice, A. G. (2003). Faculty perceptions of graduate international students: The benefits and challenges. Journal of Studies in International Education, 7(4), 379-403.

Van Driel, J. H., Beijaard, D., \&Verloop, N. (2001). Professional development and reform in science education: The role of teachers' practical knowledge. Journal of research in science teaching, 38(2), 137-158. 